\title{
The Impact of Psychological Violence on Children and Legal Protection Efforts in Indonesia
}

\author{
Gladi A.R. Dendape*1 J. Ronald Mawuntu ${ }^{2}$ \\ Wulanmas A.P.G. Frederik ${ }^{2} \quad$ Emma V.T. Senewe ${ }^{3}$ \\ 1.PhD Student, Departement of Law Studies, Postgraduate Program, \\ Sam Ratulangi University, Manado, Sulawesi Utara, Indonesia \\ 2.Profesor Departement of Law Studies, Postgraduate Program, \\ Sam Ratulangi University, Manado, Sulawesi Utara, Indonesia \\ 3.Departement of Law Studies, Postgraduate Program, \\ Sam Ratulangi University, Manado, Sulawesi Utara, Indonesia
}

The research is financed by Postgraduate Programe, Departement of Law, Sam Ratulangi University, Indonesia

\section{Abstract}

Children are an inseparable part of human survival and the survival of a nation and state. Undang- UndangDasar Negara Republik Indonesia Tahun 1945 Article 28b paragraph (2) states that "every child has the right to survival, to grow and develop and has the right to protection from violence and discrimination". This study discusses the impact of psychological violence and legal protection efforts in Indonesia. The research method used is normative juridical, with descriptive analytical research specifications that provide an in-depth description of a situation related to the problem being studied. The results of the study basically show that violence against children still frequently occur in Indonesia. Psychological violence in children has a very dangerous impact and can affect a child's psychological life. Efforts to guarantee protection of children in Indonesia have not been maximized, although positive laws in Indonesia have provided guarantees for child protection. Protection of children from acts of violence require the participation of the community, family, non-government institutions, and all other parties. Keywords: children's rights, psychological violence, legal protection

DOI: $10.7176 / J L P G / 82-11$

\section{INTRODUCTION}

\section{BACKGROUND}

Children are potential candidates and the future generation of national and state ideals. Children are an inseparable part of human survival and the survival of a nation and state. In this important role of children, children's rights have been explicitly stated in the constitution, that the State guarantees every child the right to live, grow, and develop and are entitled to protection from violence and discrimination.

The best interests for children should be practiced as the best interests for the survival of humanity. They deserve the opportunity to grow and develop optimally, physically, mentally, socially, and spiritually. The period of child development should be filled with positive things such as being guided, guarded, cared for, and educated well and far away from all forms of violence and discrimination and living in a good environment for growth and development. Therefore, all forms of violence against children need to be prevented and overcome. ${ }^{1}$

The position of children who are vulnerable to human rights violations requires special protection, because children do not have sufficient capacity to protect themselves if they are in an emergency situation, such as children facing the law, isolated children from minority groups, economically and or sexually exploited children, trafficked children, children who are victims of narcotics, alcohol, psychotropic abuse and other addictive substances (drugs), abducted children, children victim to physical and/or mental violence, children with disabilities, and children victim to mistreatment and neglect.

Undang- UndangDasar Negara Republik Indonesia Tahun 1945 Article 28b paragraph (2) states that "every child has the right to survival, to grow and develop and has the right to protection from violence and discrimination". In reality, child protection in Indonesia is still far from the objective of the Article. So many Indonesian children are victims of violence both in their homes and outside of their homes.

Various types of violence are exercised to children and the perpetrators are usually people who have close relations with them. Today's violence against children can occur anywhere, such as: in school, on the streets, and can even occur at home where the child lives. Children in Indonesia are often victims of various forms of violence including physical violence, psychological violence, sexual violence, and neglect.

As for the forms of violence that can be experienced by children, namely: 1). Physical violence, which is an act that results in pain, illness, or serious injuries; 2). Psychological violence, which results in fear, loss of trust, loss of ability to act, feelings of helpless and/or severe psychological suffering; 3). Sexual violence, including forced sexual relations with people who live in the household; and forced sexual relations by one person within

${ }^{1}$ Abu Hurairah, Child Abuse (kekerasanterhadapAnak), EdisiRevisi, Nuansa, Bandung, 2007, p.11. 
the household with another person for commercial purposes and/or other purposes. 4). Household neglect, including the act of abandoning a person within the household, even though according to the applicable law or an agreement he is obliged to give life, care, or maintenance to said person; and actions that result in economic dependence by limiting and or prohibiting work inside or outside the household so that the victim is under the control of that person.

This study specifically addresses the forms of psychological violence experienced by children and legal protection efforts in Indonesia. According to the researcher, psychological violence has a very dangerous impact on children's growth and development. Psychological violence will be inherent in the child until the child becomes an adult. Children will be affected by the conditions in which they were raised by violence.

\section{PROBLEMS OF THE STUDY}

Based on the description from the above mentioned background, the researcher has identified 2 problems that become questions in this study. First, how are the forms of psychological violence and its impact on children in Indonesia?; Second, how is the legal protection against psychological violence on children in Indonesia?

\section{RESEARCH OBJECTIVES}

This study aims to examine and analyze the forms of psychological violence against children in Indonesia and legal protection in Indonesia.

\section{THEORETICAL FRAMEWORK}

\section{Children's rights as human rights}

Talking about human rights means talking about the existence and protection of human life.Human rights are the culmination of human conceptualization of themselves. Therefore, if it is mentioned as a conception, it means that the optimization of reformulation of strategic thinking about the protection of basic rights possessed by humans continues to develop. ${ }^{1}$ Human rights are a dimension of the totality of human life. Human rights exist not because they are given by the people and the good of the country, but based on dignity as human beings. Recognition of human existence signifies that humans are living beings created by God Almighty that deserve positive appreciation. $^{2}$

Humans were created by God with a set of rights that guarantee their degree as human beings, namely the rights obtained from birth as human beings which is the gift from God. ${ }^{3}$ Jack Donnelly argues that "human rights are the rights that human beings possess becausethey are human beings". ${ }^{4}$ Human rights values are values that are not specifically found in the scope of certain cultures or religions, but are values that exist in all cultures and religions in the world. Almost all the values in the world glorify respect for life and human dignity. ${ }^{5}$

The philosophy of human rights is to guarantee respect for everyone, human dignity and independence from all forms of actions that are not in accordance with the dignity of humans in carrying out their lives in the community. ${ }^{6}$ Therefore, all human beings have equal human rights without discrimination, and these rights are interrelated, dependent on each other and cannot be divided. Human Rights are also a value system that is universally recognized. National and regional privileges and a variety of different historical, cultural, and religious backgrounds, all countries have an obligation to protect human rights and basic freedoms. ${ }^{7}$

Children's rights are special rights that aim to protect all persons under the age of 18 years. The human rights pledged in the Universal Declaration of Human Rights apply to all humans regardless of how old they are, and therefore children also get the same benefits as adults. However, because of their vulnerable position in the community, children also receive special rights that give them special protection. ${ }^{8}$

According to J. Ekelar, children need human rights with special qualifications in accordance with the characteristics of children for the following reasons:

1. Children are a vulnerable group and need special protection;

2. Children are a group of people that have different needs and rights than adults;

\footnotetext{
${ }^{1}$ Majda El Muhtaj, Dimensi-Dimensi HAM menguraiHakEkonomi, Sosial, danBudaya, PT. RajaGrafindoPersada, Jakarta, 2008 , p 6-7.

2 MohamadKholid, HakAsasiManusia Dan SistemHukumPidanaNasionalDalam Negara Hukum Indonesia, PUSHAM UII bekerjasamadenganNorskSenter For Menneskerettigheter Norwegian Centre For Human Rights, Training Tingkat Lanjut Rule Of Law Dan HakAsasiManusiaBagiDosenHukum Dan Ham, Jakarta, 3-6 Juni 2015, p.7.

${ }^{3}$ JimlyAsshiddiqie, DemokrasidanHakAsasiManusia, MahkamahKonstitusiRepublik Indonesia. p.1-2

${ }^{4}$ Jan Berting, et al., Human Rights in a Pluralist World: Individuals and Collectivities, First. Edition, (London: Meckler, 1990), p. 33

${ }^{5}$ ZainalAbidin, PerlindunganHakAsasiManusia di Indonesia, MakalahdisampaikanpadaPelatihan HAM bagiPanitia RANHAM Prov. Sumatera Barat, Padang, 13 Juni 2013, p.3.

${ }^{6}$ Jacques Robert, "Constitutional and International Protection of Human Rights Competing or Complementary System", Human rights Law Journal, Vol 15, No 1-2, 31 March 1994, NP Engel Publisher, hlm.2. DikutipdalamAjiWibowo, HakAsasiManusiadanImplementasinya di Indonesia, Unpad Press, Bandung, 2010, p.1.

${ }^{7}$ ZainalAbidin, Op. Cit, p.4.

${ }^{8}$ https://equitas.org/wp-content/uploads/2011/12/modul-2-hal-1-38.pdf [accessed on 10/10/2018]
} 
3. Children have specific rights as part of human rights ${ }^{1}$

Children's rights aim to ensure that every child has the opportunity to reach their full potential. Children's rights determine that children, without discrimination, must be able to develop fully, have access to education and health care, grow in an appropriate environment, get information about their rights, and actively participate in society. Children's rights are to protect children from violence and abuse. Children's rights encourage mutual respect between humans. Appreciation for children's rights can only be achieved fully if everyone, including the children themselves, recognize that everyone has the same rights, and then applies them to attitudes and behaviors that respect, include, and accept others. ${ }^{2}$

\section{Concept of Legal Protection}

Although it is not possible to have a complete definition of what the law is, Utrecht provides guidance on the definition of law, namely that "the law is a set of rules (orders and restrictions) that take care of the code of conduct of a society and therefore it must be obeyed that society". Legal functions in the development of society are believed to be a means of regulating public relation rules as well as a means to realize physical and inner social justice. $^{3}$

Legal protection has the meaning of protection by using the law or protection provided by law, aimed at protecting certain interests, namely by making the interests that need to be protected into a legal right. ${ }^{4}$ The most basic interest of every citizen is the protection of their rights as human beings. Legal protection in guaranteeing the rights of citizens must be equal and without discrimination.

Fitzgerald, who explained Salmond's theory of legal protection, stated that the law aims to integrate and coordinate various interests in society as a traffic interest, the protection of certain interests can only be done by limiting various interests on the other. ${ }^{5}$ The legal interest is to take care of human rights and interests, so that the law has the highest authority to determine human interests that need to be regulated and protected. ${ }^{6}$

Whereas according to Philipus M Hadjon, legal protection is a protection of dignity and recognition of human rights owned by legal subjects. Legal protection is generally in the form of a written regulation, so that its nature is more binding and will result in sanctions that must be imposed on those who violate it. ${ }^{7}$

Legal protection is always related to the role and function of law as a regulator and protector of the interests of society, Bronislaw Malinowski in his book 'Crime and Custom in Savage', states "that the law does not only play a role in conditions of violence and conflict, but also plays a role in daily activities". ${ }^{8}$

The law becomes an important instrument in protecting and upholding human rights in a country. Speaking of human rights will always be related to legal issues, this is because human rights need legal means to guarantee their existence in real life. Without legal means, human rights will be difficult to manifest in its enforcement. ${ }^{9}$ The law is nothing but protection of human interests in the form of norms or rules. ${ }^{10}$

\section{Children According to Legislation in Indonesia \\ a. Undang-UndangDasar 1945}

The definition of a child or the position of a child determined according to Undang-UndangDasar Negara Republik Indonesia Tahun 1945 is contained in Article 34. This article has a special meaning on the understanding and status of children in the political field, because that is the essence of the basic position of children, namely, children are legal subjects of the national legal system, that must be protected, cared for, and nurtured to achieve child welfare. The understanding according to Undang-UndangDasar Negara Republik Indonesia Tahun 1945 and the understanding of politics emphasizes the rights that must be obtained by children from national and state communities; or in other words the government and society are more responsible for juridical and political social problems that exist for a child.

The provision requires that the interests of national and state development must prioritize children, as a source of aspirations for the birth of new generations of heirs of a great civilization, with high scientific and technological abilities and then being able to prosper Indonesian society. Article 34 Undang-UndangDasar Negara Republik Indonesia Tahun 1945 states that "poor and neglected children are nurtured by the State" which contain

\footnotetext{
${ }^{1}$ Pulthoni, dkk, HakAnakAdalahHakAsasiManusia: ModulPelatihanAnak Yang BerkonflikdenganHukum (ABH) UntukAnakJalanan, The Indonesian Legal Resource Center (ILRC)-Australian Aid, Jakarta, 2012,p.34.

${ }^{2}$ https://equitas.org/wp-content/uploads/2011/12/modul-2-hal-1-38.pdf, Op. Cit.

${ }^{3}$ Pulthoni, dkk, Op. Cit, p.17.

${ }^{4}$ Harjono, PerlindunganHukumKetenagakerjaan, PT. Raja GrafindoPersada, Jakarta, 2008, p.85.

${ }^{5}$ SatjiptoRahardjo, IlmuHukum, PT. Citra AdityaBakti, Bandung, 2000, p.53.

${ }^{6}$ Ibid, p.69.

${ }^{7}$ Ibid, p. 205.

${ }^{8}$ R. Soeroso, PengantarIlmuHukum, SinarGrafika, Jakarta, 2006, p.13.

${ }^{9}$ Syamsiar Julia, Pelanggaran Ham Dan PerananPolriDalamPenegakanHukum Di Indonesia, Jurnal Equality, Vol. 11 No. 2 , Agustus, 2006, p.115.

${ }^{10}$ SudiknoMertokusumo, MengenalHukumSuatuPengantar, Liberty, Yogyakarta, 2003, p. 39
} 
specificities for the grouping of children as abandoned children and then used as objects of development, formation, maintenance with the aim that Indonesian children will be able to live decent lives, a life full of prosperity.

\section{b. Other Legislation Regulations}

Legal regulations regarding children have differences, especially regarding the age of the child. The difference in determining the age of a child is also recognized by international law, as stated in the Convention on Childern's Rights 1989 Article 1 that the adult age limit in the law of a country may be different from the provisions of the convention on children's rights.

Article 1 paragraph (2) of Act No. 4/1979 on Child Welfarestipulates that: "A child is someone who has not reached the age of 21 years and has not yet married ". It differs from what is stipulated in other Laws, such as: Act No. 13/2003 on EmploymentArticle 1 paragraph (26) which states that: "Children are every person under the age of 18 (eighteen) years; Act No. 35/2014 on Child Protection Article 1 paragraph (1) which stipulates that: "A child is a person who is not 18 (eighteen) years old, including a child who is still in the womb".

The concept of the age of the child in this study uses the age limit set in accordance with the provisions of the Employment Act and the Child Protection Act. The age regulation of children in both laws is in line with those stipulated in Article 1 paragraph (5) of Act No. 39/1999 on Human Rights, which states that: "Children are all human beings under 18 (eighteen) years of age and not married, including children who are still in the womb, if this is at their interest". Furthermore, in Article 52 of Act No. 39/1999 on Human Rightsit affirms that every child has the right to protection by parents, family, society, and state, and children's rights are human rights, and for the sake of their rights the child is recognized and protected by the law even in the womb.

\section{DISCUSSION}

\section{Psychological Violence and Its Impact on Children in Indonesia}

Elizabeth Kandel Englander argues that, in general, violence is aggressive behavior with the intention of causing damage, both physical and psychological. The word 'intention' according to her is the core, this is because if physical or psychological harm occurs accidentally, without any intention, it is not violence. ${ }^{1}$ The United Nations stated that, "Any act by which severe pain or suffering, physical or mental, is intentionally inflicted on a person" 2

Based on the understanding mentioned above, it can be understood that violence is an intentional act with the intention of causing detrimental effects both physically and psychologically. This is also as stated by Joan Bondurant, "the willful application of force that is intentionally the person or group against whom it is applied. (here) injury is understood to include psychological as well as physical harm ".3

Violence occurs when a person uses his power, authority, and position to intentionally harm others, not by accident. Violence also includes threats and actions that can cause injury and loss. The resulting injury can be physical wounds, feelings, thoughts, which are detrimental to health and mental state. Violence towards is any form of action that hurts and harms the physical, mental, and sexual being as well as insults, which include: neglect and ill-treatment, exploitation - including sexual exploitation, and trafficking or buying and selling children, while Child Abuse is all forms of violence against children committed by those who should be responsible for the child or those who have power over the child, who should be able to be trusted, for example parents, close family, and teachers.

Psychological violence, include the delivery of harsh and dirty words, showing pornographic books, pictures, or films to children. Children who get this treatment generally display behavioral symptoms, such as withdrawal, shyness, crying when approached, fear of going out of the house and fear of meeting other people. ${ }^{4}$

Jack Canfield, an expert in self-confidence, in his research on 100 children found that each child received an average of 460 negative comments or criticisms and only 75 positive or supportive comments in one day. Negative comments are very dangerous for emotional development and intelligence of children. ${ }^{5}$ What about children in Indonesia? Indonesian children are still confined to violence. The Indonesian Child Protection Commission (KomisiPerlindunganAnak Indonesia / KPAI) stated that violence against children always increases every year. From the results of KPAI's monitoring from 2011 to 2014, there was a significant increase. "In 2011 there were

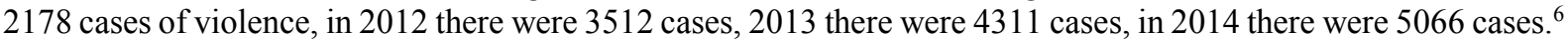
During April-July 2018, the KPAI in the field of education handled and supervised as many as 33 cases of violations of children's rights, consisting of: (1) child victims to policy, 10 cases $(30.30 \%)$; (2) extortion in schools,

\footnotetext{
${ }^{1}$ Elizabeth Kandel Englander, Understanding Violence, Mahwah-New Jersey: Lawrence Erlbaum Associate, Publishers London. 2003 , p. 2. ${ }^{2}$ Linda Valerian, Human Rights and The Politic of Terror, Human Rights : An Overview, Defining torture, Gary E. McCuen Publication Inc., 1955 , p. 17.

${ }^{3}$ KoesparmonoIrsan, HakAsasiManusiaDikaitkanDenganPenegakanHukum, Alumni, Bandung, 2000, p. 245.

${ }^{4}$ Edi Suharto, Pembangunan, KebijakanSosialdanPekerjaanSosial, LembagaStudi Pembangunan SekolahTinggiKesejahteraanSosial, Bandung, 1997, p. 365-366

${ }^{5}<$ http://bennisetiawan.blogspot.com/2007/kekerasan -psikis-lebih-berbahaya-dari-kekerasan-fisik> (can be read in Jawa Post, Friday, 27 July 2007). [accessed on 19/05/2018]

${ }^{6}$ Davit Setyawan, KPAI: PelakuKekerasanTerhadapAnakTiapTahunMeningkat, 14 JUNE 2015, <http://www.kpai.go.id/berita/kpai-pelakukekerasan-terhadap-anak-tiap-tahun-meningkat> [accessed on 6/10/2018]
} 
2 cases $(6.60 \%)$; (3) not allowed partake in exam, 2 cases $(6.60 \%)$; (4) Sealing of schools/school lockdown, 1 case (3..30\%); (5) children dropped out and expelled from school, 5 cases (15\%), and the highest cases were 13 victims of violence / bullies $(39 \%){ }^{1}$

The forms of psychological violence are difficult to know, and especially difficult to report. The psychological violence that had emerged publicly was the action of the Anti-Terrorism Detachment 88 against Abu Dujana's child. Abu Dujana's son suffered severe depression as a result of watching his father be arrested by the authorities. Another thing, as noted by the National Commission on Violence against Humanity (KomisiNasionalPerlindunganAnak / Komnas $P A$ ), is that a 9-year-old child who is a victim of violence has the desire to kill his mother.

The emergence of violence has a very heavy psychological effect on the victims. Emotional and personality conditions generally cause severe shocks, resulting in unbalanced conditions. Imbalance occurs because the information or experience received is not in accordance with the scheme that is owned, for example about the father figure who should protect them turns out to be that the person who often hits them. In the case of Dovi, the scheme (psychological structure) formed about his father became so bad when saying that he had a grudge against his father. If he continues to maintain this scheme, it certainly will not bring goodness to his future adaptation to the environment.

Another case happened in early December in the city of Kediri, the murder of Faisal Amanullah (4 years) by IE, an 11-year-old child. IE was very angry when he was often dubbed as "Bald" by his friends and that was imitated by Faisal. Actually "bald" is an insult because his father is bald. Besides that, he often saw how angry his father was, and IE wanted to try to be like the heroes on television, to frighten his friends so they would not insult him again, which resulted in Faisal's death. While in Tegal, Central Java, on December 21, Eva suffered a broken bone and a coma for a week due to attempting suicide from the third floor of PasarPagiTegal. Eva Rosnani, who is only 15 years old, was determined to commit suicide because she was left by her cheating boyfriend. Actually, jumping from the third floor was not Eva's first try. Previously she had tried slashing her hands with a razor blade. ${ }^{2}$

According to Dr. SetoMulyadi, a child psychologist who is also the general chairman of the National Commission for Child Protection (KomisiNasionalPerlindunganAnak/ KNPA), many children are now trapped in various social situations that are not very conducive. They are stressed by pressures in the family, school, and community environment, leading to aggressive behavior that is often uncontrolled. The provision of an environment that is not conducive to children, excessive pressure, and things that psychologically cause this child to be injured is what Dr. SetoMulyadi, or KakSeto, emphasizes as psychological violence. It can be in the form of accusations, giving bad labels to children, threats, accusations or curses, harsh words, and threatening movements, making children feel hurt, making children feel afraid, stressed and so on.

In general, it is said that the main consequences of psychological violence from parents, teachers, the environment and government regulations are several things. First, the models of violence that are seen and accepted will be imitated by the child. Second, the destruction of the child's mental development. Children become unable to concentrate, children are stressed, children become afraid, children become motivated to commit violence, and so on. "So it is always said that if children commit acts of violence against other people, it is better for children not only to be positioned as accused or accused of crimes, but also to be treated as victims. Because the child is a victim of violence that colors their lives in a way that they slip and are trapped in being forced to have conflicts with the law," said KakSeto. ${ }^{3}$

The pattern of education, socialization, and interaction in the family is very influential on the process of forming children's behavior. Violence of children can arise when parents are less concerned about the environment of the child's interaction. Various opinions expressed by experts about the causes of the emergence of violent behavior in the psyche and environment of children, but most agree that violent behavior in children is more influenced by the background pattern of education in the family.

Psychological violence in schools following the Unicef survey, in Central Java, as many as $80 \%$ of teachers claimed to have punished children by shouting at them in front of the class, $55 \%$ of teachers claimed to have told students to stand in front of the class as punishment. In South Sulawesi, $90 \%$ of teachers claimed to have punished students by standing in front of the class, $73 \%$ had yelled at students in front of the class and $54 \%$ had told students to clean or wipe down the toilets. In Sumatra, $90 \%$ of teachers claimed to have told students to stand in front of the class as punishment and $80 \%$ had yelled at students rudely in front of the class. "All these forms of punishment embarrass and undermine the dignity and abilities of children often occur in schools in Indonesia," the report said. Unfortunately most teachers do not realize that what they are doing is a violation of children's rights and violence

\footnotetext{
DediHendrian, Pers Release EksposePengawasanKpaiBidangPendidikan April-Juli 2018 Trauma Berat, CederaFisikSampaiKematianAkibatKekerasan Di Sekolah, 13 AUGUST 2018, <http://www.kpai.go.id/berita/pers-release-eksposepengawasan-kpai-bidang-pendidikan-april-juli-2018-trauma-berat-cedera-fisik-sampai-kematian-akibat-kekerasan-di-sekolah> [accessed on $6 / 10 / 2018]$

${ }^{2}<$ http://shintaksari.multiply.com/journal/item/273/trauma-anak-berkepanjangan-akibat-kekerasan psikologis $>$ [accessed on 17/4/2018] ${ }^{3}$ Ibid
} 
against children that has a legal impact.

The above violations do not include bullying problems from the social environment. "The effect of bullying is quite large, because they are on a group level. If they are not in accordance with the group norms, they seems to be completely destroyed," said KakSeto. This is where the teacher's task is expanded, not just teaching the curriculum. Teaching that is more complete and meaningful is based on love, mutual respect and mutual need, a feeling of love for children like their own children to create a close and intimate inner atmosphere.

People in general do not realize the extent of this child abuse effect, said Valerie Bivens, a member of the California Social Worker for Child Protective Service, as quoted by Dave Pelzer. ${ }^{1}$ To see the complexity of the problem faced, as a result of the influence of child abuse, it can be seen from the following expert opinions ${ }^{2}$, for example, children who suffer from violence, exploitation, abuse and neglect face risks of: shorter lifespans; poor physical and mental health; educational issues (including school drop-outs); limited ability as a parent later on in life; becoming a bum.

In addition Indonesian Child Welfare Foundation (YayasanKesejahteraanAnak Indonesia / YKAI) also concluded that violence can cause children to lose the most basic things in their lives and in turn have a very serious impact on the lives of children in the future, including ${ }^{3}$ : Permanent bodily defects; Failure to learn; Emotional disorders can even lead to personality disorders; Poor self-concept and inability to trust or love others; Passivity and withdrawal from the environment, afraid of fostering new relationships with others; Aggressive and sometimes carry out criminal actions; Being a persecutor as an adult; Drug or alcohol use; Death.

The psychological effects on children who are victims of violence and abuse can be lifelong, such as: a sense of low self-esteem (inability to relate to peers), a period of reduced attention (reduced attention span) and learning disorders. In some cases, violence can cause psychiatric disorders, such as: depression, excessive anxiety, or dissociative identity disorder, and also the risk of suicide. ${ }^{4}$

A clearer picture of the effects of acts of violence on children can also be seen from Moore's explanation in observing several cases of children who were victims of physical abuse. He revealed that the effects of such acts of violence are so broad and can generally be classified into several categories. ${ }^{5}$

Its influence becomes negative and aggressive and easily frustrated; some become very passive and apathetic; there are those who do not have their own personality, what is done throughout their lives is only fulfilling the parental extension, they are not able to appreciate themselves (chronically low self-esteem); some have difficulties establishing relations with other individuals; and what seems to be the most severe is the emergence of extraordinary hatred towards oneself which they then take actions of self-harm such as suicide and so on, besides the psychological consequences, Moore also found physical damage, such as abnormal body development, also damage to the nervous system, etc. ${ }^{6}$ Based on this description, psychological violence is also closely related to physical violence. The impact of acts of violence against children is so devastating, perhaps not many people realize that physical beatings can cause emotional and psychological damage to children.

\section{Child Protection Against Psychological Violence in Indonesia}

Internationally, children's rights have been established through the UN General Assembly on November 20, 1959, through the declaration of Children's Rights, it is expected that all parties - individuals, parents, social organizations, governments, and communities - recognize these rights and encourage all efforts to fulfill them. Efforts to provide protection to children are actually done in Indonesia. There are a number of laws and regulations that are formed through the legislative process or the results of ratification which specifically regulates the rights of children.

Through Act No. 4/1979 on Child Welfare, the government stipulates that: Children have the right to welfare, care, nurture, and guidance based on love both in their families and in special care to grow and develop naturally; Children have the right to service to develop their abilities and social life, in accordance with the culture and personality of the nation, to become good and useful citizens; Children have the right to care and protection, both in the womb and after being born; Children have the right to protection from the environment that can harm or hinder their natural growth and development. ${ }^{7}$

Besides describing children's rights through Act No. 4/1979 on Child Welfareas statedabove, the Indonesian government has also ratified the UN Convention on the Children's Rights through Presidential Decree No. 39/1990.

\footnotetext{
${ }^{1}$ Dave Pelzer, A Child Called "It", 1995, SebuahKisahNyataPerjuanganSeorangAnakUntukBertahanHidup (DananPriatmoko, AlihBahasa), Jakarta, GramediaPustakaUtama, 2003, p. 161.

2 KusnandiRusmil, $2004 \quad$ "PenganiayaandanKekerasanTerhadapAnak, MakalahDisampaikanpada seminar sehari "PenangananKorbanKekerasanpadaWanitadanAnak," 19 Juni di RumahSakitHasanSadikin Bandung, pl.161.

${ }^{3}$ Edi Suharto, Pembangunan, KebijakanSosialdanPekerjaanSosial, Op. Cit, p. 367-368

${ }^{4}$ Ibid.

${ }^{5}$ FentiniNugroho, 1992, StudiEksploratifMengenaiTindakanKekerasanTerhadapAnakDalamKeluarga, DalamJurnalSosiologiMasyarakat, jakarta. JurusanSosiologi FISIP UI, GramediaPustakaUtama, 1992, p.41.

${ }^{6}$ Ibid.

${ }^{7}$ Pasal 2 Undang-undangNomor 4 Tahun 1979 tentangKesejahteraanAnak (Article 2 of Act No. 4/1979 on Child Welfare)
} 
The Convention on Children's Rights (CRC) is the most complete international legal instrument, because it covers all aspects of children's rights, including political, economic and social rights as well as the responsibilities of the state, society, and parents to fulfill their regulated rights. There is a general classification of the total rights contained in the Convention on Children's Rights known as 3 (three) 'P', that is: ${ }^{1}$

1. Provision: Children's rights must be given through social services and other basic services, from health care and education, and social security benefits to achieving an adequate standard of living;

2. Protection: The right of a child to be protected from all kinds of acts of violence, including abuse, neglect, forms of commercial sexual exploitation and etc, torture and arbitrary detention;

3. Participation: The right of children to express their views (participate) in all decisions that affect the lives of children and society as a whole.

Furthermore, since the enactment of Act No. 23/2002 on Child Protectionon October 22, 2002, protection for Indonesian children has a stronger legal basis. This law has been in force for approximately 12 years and was changed to Act No. 35/2014 on Amendments to Act No. 23/2002 on Child Protection. Children's rights are relatively more complete and included in Act No. 35/2014 on Amendments to Act No. 23/2002 on Child Protection.

For example, as stipulated in Article 13 of Act No. 35/2012, it is said that every time in the care of parents, guardians, or any other party responsible for care, the child is entitled to be protected from treatment from: Discrimination; Economic and sexual exploitation; Neglect; Cruelty, violence and persecution; Injustice; and other wrong treatments. Then it was explained that the parents, guardians, or caregivers of the child who did all forms of treatment as referred to in paragraph (1), then the offender is subject to a penalty. Furthermore, Article 15 of Act No. 35/2012, states that every child has the right to receive protection from: Utilization in political activities; Engagement in armed disputes; Engagement in social unrest; Engagement in events that contain elements of violence; and Engagement in warfare.

Based on these two Articles, children get protection not only from actions taken by outsiders (in this case not family and guardians), guarantees for child protection are also given to prevent children from prohibited actions, which may be carried out by the closest parties (in this case family and guardian). In other words, guaranteeing the protection of children's rights is also emphasized in the scope of care and life of children in the family.

In addition to providing protection for children from violations committed by family and other people, the Act also gives special attention to children who are faced before the law. Under these conditions, according to Article 16 it is said that, every child has the right to receive protection from the target of mistreatment, torture, or imposition of inhuman punishment. Every child has the right to obtain freedom according to the law. Arrest, detention, or criminal imprisonment is only done according to the sentence and can only be given as a last resort.

In Article 17 it is also said that: Every child deprived of his freedom has the right to: Get humane treatment and their placement is separated from adults; Obtain legal assistance or other assistance effectively in every step of the applicable legal effort; and Defending themselves and obtaining justice in front of a juvenile court that is objective and impartial in a closed session to the public. Meanwhile, every child who is a victim or perpetrator of sexual violence or who is dealing with the law has the right to be kept secret. Furthermore, Article 18 states that every child who is a victim or criminal offender has the right to receive legal assistance and other assistance.

Government efforts on psychological violence that occur in children are reflected in the regulation of Article 59. In the provisions of the Article, it is mandated that there be special protection for children who are faced with various conditions, including:

a. Children in emergency situations;

b. Children who are faced with the law;

c. Children from minority groups and are isolated;

d. Children who are exploited economically and/or sexually;

e. Children who are victims of narcotics, alcohol, psychotropic and other addictive substances abuse;

f. Children who are victims of pornography;

g. Children with HIV or AIDS;

h. Children abducted, sold, and/or trafficked;

i. Children victim to physical and/or psychological violence;

j. Children victim to sexual crimes;

k. Children victim to terrorism networks;

1. Children with Disabilities;

$\mathrm{m}$. Children victim to mistreatment and neglect;

In these conditions, the mandated effort is in the form of rapid handling including psychological treatment and/or rehabilitation, psychosocial assistance during treatment to recovery, and the provision of protection and assistance in every judicial process.

In carrying out the implementation of child protection, it is the responsibility of the State, Government and

${ }^{1}$ Pulthoni, dkk, Op. Cit, p.38. 
Regional Government. In addition to giving responsibility to the state, the implementation of child protection also provides responsibility to the community, parents and family. Government responsibility includes policy formulation, support for facilities, infrastructure, and availability of human resources and supervision in the implementation of child protection.

Community responsibility is carried out by involving community organizations, academics, and child observers. The general public has an obligation to participate in child protection activities. The community can supervise at the lowest level, for example giving assistance if there are cases of violations of children's rights in the environment around their homes, recording and reporting if they see potential vulnerability to violations of children's rights to the authorities.

Meanwhile, the parents' responsibility is to care for, nurture, educate, and protect the children; let children grow according to their abilities, talents, and interests; prevent the occurrence of early marriage (at children's age); and providing character education and planting values for children. In the case of a parent who does not exist, or is not known to exist, or because of a reason that they cannot carry out their obligations and responsibilities, responsibility can be transferred to the family.

The efforts that have been made are related to the protection and fulfillment of children's rights, namely: ${ }^{1}$

1) The government has a program, for example: the issuance of free birth certificates for children; Education about ways to care without violence to parents and teachers; Health services for children; Increase the basic education budget and eliminate the cost of basic education.

2) The House of Representatives or the Regional People's Representative Assembly make laws or regulations to protect children from acts of violence and exploitation, threaten the perpetrators with the threat of punishment so that they are expected to cause deterrent effects.

3) Law enforcement officials (police, prosecutors) and justice enforcers (judges) process every violation of children's rights firmly, indiscriminately, and impose sanctions that are commensurate with the violations committed.

Efforts to ensure the implementation of child protection can be carried out properly, the government also established an independent state institution that was given a mandate to improve the effectiveness of the implementation of child protection, namely the Indonesian Child Protection Commission (KomisiPerlindunganAnak Indonesia / KPAI). As stated in Article 76 of the Act on Child Protection, the task of the $K P A I$ is to:

a. supervise the implementation of protection and fulfillment of the Rights of the Child;

b. provide input and proposals in the formulation of policies regarding the implementation of Child Protection.

c. collect data and information about Child Protection;

d. receive and review complaints from the public regarding violations of the children's rights;

e. mediate on disputes over violations of Children's Rights;

f. cooperate with institutions formed by the Community in the field of Child Protection; and

g. give a report to the authorities about the alleged violation of this Act.

In Article 76, it describes what activities should be carried out by the KPAI to make effective the supervision of child protection. The meaning of the effectiveness lies in the supervision side. The existence of the KPAI is intended as a corrective supervisor who keeps the protection of children on track, while at the same time spurring child protection organizers and stakeholders everywhere consisting of States, governments, communities and families to do their utmost and not violate agreed principles regarding child protection.

The function of the KPAI differs from the function of the Ministry of Women's Empowerment and Child Protection (KementerianPemberdayaanPerempuandanPerlindunganAnak / KPPPA). The function of KPPPA is policy making in the executive region that synchronize various aspects of child protection carried out by all government apparatus both at the central and regional levels. In this case, KPPPA also has its own monitoring and evaluation tools, including those for imposing internal sanctions and giving awards. The monitoring, evaluation, and supervision carried out by KPPPA have different meanings than those carried out by KPAI. Where what $K P P P A$ does is within the administrative area and within the framework of inter-agencies so that there is more coordination in the government. Whereas what is done by KPAI is outside of the territory of the State organizer in the executive sense. Although KPAI is a State institution, its independent nature causes KPAInot to be in the internal coordination area. $K P A I$ can give reprimands, publications, recommendations, and other matters deemed necessary to all State Administrators, but KPAI cannot impose internal or administrative sanctions. ${ }^{2}$

The government provides two steps that can be taken as an effort to protect or further handle child victims of violence, namely rehabilitation and restitution. Rehabilitation is regulated in the Regulation of the Minister of Women Empowerment and Child Protection of the Republic of Indonesia No. 2/2011 on Guidelines for Handling

${ }^{1}$ AnissaNurFitri, PerlindunganHak-HakAnakDalamUpayaPeningkatanKesejahteraanAnak, Prosiding Ks: Riset\&Pkm, Volume: 2 Nomor: 1, p.49

${ }^{2}$ KomisiPerlindunganAnak Indonesia, LaporanKinerja KPAI 2017, KomisiPerlindunganAnak Indonesia, Jakarta, 2017 , p.16. 
Child Victims of Violence. Meanwhile, restitution is regulated in Government Regulation No. 43/2017 on the Implementation of Restitution for Children Who Become Victims of Crime.

Handling child victims of violence by means of rehabilitation can affect 2 things, namely health rehabilitation and social rehabilitation. The health rehabilitation mechanism follows the health care system as stated in the minimum service standard for handling women and children victims of violence. If the victim needs health rehabilitation, it can be handled at the health center capable of managing $K T P / A$. If the victim needs an advanced health care service (specialist) they can be referred to a hospital that has integrated services (integrated service $(P P T)$. If there is no $P P T$ at the hospital, then referral of cases that require specialist medical services can be done in central hospitals, regional general hospitals, the Indonesian National Police and the private sector. If the victim needs social rehabilitation where the victim experiences psychosocial and psychological disorders, the psychosocial team will provide counseling and therapy as needed. If both the conditions of the victim's health and social have been declared recovered, then with the consent of the victim, they can get legal assistance in the form of assistance and defense by law enforcement elements namely the Police (UPPA), Prosecutors' Office, Judges, and Legal Aid Institutions.

Restitution is a compensation payment charged to the perpetrator based on a court decision that has permanent legal force for material and/or immaterial losses suffered by the victim or their heirs. In the Government Regulations it is stated that every child who is a victim of a crime has the right to obtain restitution. Children who are victims of criminal acts include children who are facing the law, children who are economically or sexually exploited, children who are victims of pornography, children who are abducted, sold, or trafficked, children victim to physical or psychological violence, and children who are victims of sexual crimes. Requests for restitution must be submitted by the victim with a special power of attorney, while the parties given the power of attorney include the Witness and Victim Protection Agency (LembagaPerlindunganSaksidanKorban/ LPSK), Legal Aid Institutions, and institutions that handle child protection.

Institutionally and according to the current legal framework, it is conducive enough to promote children's rights, but it is recognized that there are still some gaps. The widespread violation of children's rights was responded to by the State Minister for Women's Empowerment, MeutiaHattaSwasono. It is said that, currently the legislation has not been implemented consequently to guarantee and protect the rights and protection of women and children. Children are often exploited and receive acts of violence; pressure on the basic right to a decent life, especially education and health of children are still neglected. ${ }^{1}$

The implementation of child protection in Indonesia must be carried out comprehensively. In the Child Protection Act, it is stated that the implementation of child protection covers several fields of life, namely: religion, health, education, and social. Therefore, protection of children must be harmonized from the conceptual side, objectives, targets, and mechanisms to be directed, integrated and compact between the central sector and the work unit of local government.

The development of central government guidelines for regional regulations based on a systematic approach to child protection is an important and positive steps can be taken. Data on child protection must be used for more precise planning and policy making besides being needed as well as fostering central and regional government as the key to realizing the successful development of women's empowerment and protection of children at all levels and caring for children.

In addition, the important thing for the government to do is take steps related to improving the community's legal culture towards child protection. This can be done with a variety of programs, including socialization of the impact of psychological violence on children, socialization regarding the role of family and community on the psychology of a child, and the emergence of programs that contain information and education on the protection of child protection. With the increasing legal culture in the community, it will minimize violations or violence both physically and psychologically.

\section{Conclusions}

a. Children who experience psychological violence tend to be quiet, unresponsive, closed off, etc. If the condition is not dealt with quickly, there will be severe depression in the child who eventually will commit suicide.

b. The protection of these children is still not optimal; this is reflected in the high level of violence against children in Indonesia.

\section{Suggestions}

a. The government needs to take steps to educate the public. This can be done by means of dissemination of children's rights and the impact of psychological violence experienced by children.

b. The perpetrators of violence against the community both in the family and in the community need to be

\footnotetext{
${ }^{1}<$ http://www.pktpa.org/index.php/undang-undang-perlindungan-anak-belum-konsekuendilaksanakan>[accessed on 16/4/2018]
} 
processed legally and given severe sanctions. The enactment of the Child Protection Act also needs to be supported by the Regional Government and religious institutions in terms of socialization as an effort to prevent violence.

\section{References}

Asshiddiqie J, (2003). Demokrasi dan Hak Asasi Manusia, MahkamahKonstitusiRepublik Indonesia.

Berting J, et al., (1990). Human Rights in a Pluralist World: Individuals and Collectivities, First. Edition, (London: Meckler,).

Englander E,K (2003).Understanding Violence, Mahwah-New Jersey: Lawrence Erlbaum Associate, Publishers London. 2003.

Hurairah A, (2007). Child Abuse (kekerasanterhadapAnak), EdisiRevisi, Nuansa, Bandung,

Harjono (2008). PerlindunganHukumKetenagakerjaan, PT. Raja GrafindoPersada, Jakarta, 2008.

Hendrian D (2018). Pers Release EksposePengawasanKpaiBidangPendidikan April-Juli 2018 Trauma Berat, CederaFisikSampaiKematianAkibatKekerasan Di Sekolah, 13 AGUSTUS 2018, $<$ http://www.kpai.go.id/berita/pers-release-ekspose-pengawasan-kpai-bidang-pendidikan-april-juli-2018trauma-berat-cedera-fisik-sampai-kematian-akibat-kekerasan-di-sekolah> [accessed on 6/10/2018]

Koesparmono Irsan (2000). HakAsasiManusiaDikaitkanDenganPenegakanHukum, Alumni, Bandung.

Kusnandi Rusmil (2004). "PenganiayaandanKekerasanTerhadapAnak, MakalahDisampaikanpada seminar sehari "PenangananKorbanKekerasanpadaWanitadanAnak," 19 Juni di RumahSakitHasanSadikin Bandung,

Majda El Muhtaj (2008). Dimensi-Dimensi HAM menguraiHakEkonomi, Sosial, danBudaya, PT. RajaGrafindoPersada, Jakarta.

Mohamad Kholid (2015). HakAsasiManusia Dan SistemHukumPidanaNasionalDalam Negara Hukum Indonesia, PUSHAM UII bekerjasamadenganNorskSenter For Menneskerettigheter Norwegian Centre For Human Rights, Training Tingkat Lanjut Rule Of Law Dan HakAsasiManusiaBagiDosenHukum Dan Ham, Jakarta, 3-6 Juni 2015.

Valerian L (1955). Human Rights and The Politic of Terror, Human Rights : An Overview, Defining torture, Gary E. McCuen Publication Inc.,

Pelzer D. (2003). A Child Called "It", 1995, SebuahKisahNyataPerjuanganSeorangAnakUntukBertahanHidup (DananPriatmoko, AlihBahasa), Jakarta, GramediaPustakaUtama,.

Pulthoni, dkk, (2012). HakAnakAdalahHakAsasiManusia: ModulPelatihanAnak Yang BerkonflikdenganHukum (ABH) UntukAnakJalanan, The Indonesian Legal Resource Center (ILRC)-Australian Aid, Jakarta.

Robert J, (1994). "Constitutional and International Protection of Human Rights Competing or Complementary System”, Human rights Law Journal, Vol 15, No 1-2, 31 March 1994, NP Engel Publisher.

Suharto E, (1997). Pembangunan, KebijakanSosialdanPekerjaanSosial, LembagaStudi Pembangunan SekolahTinggiKesejahteraanSosial, Bandung, 1997.

Soeroso (2006)., PengantarIlmuHukum, SinarGrafika, Jakarta.

Satjipto Rahardjo (2000)., IlmuHukum, PT. Citra AdityaBakti, Bandung.

Sudikno Mertokusumo (2003). Mengenal Hukum Suatu Pengantar, Liberty, Yogyakarta.

Syamsiar Julia. (2006). Pelanggaran Ham Dan PerananPolriDalamPenegakanHukum Di Indonesia, Jurnal Equality, Vol. 11 No. 2, Agustus, 2006.

Setyawan D (2015). KPAI: PelakuKekerasanTerhadapAnakTiapTahunMeningkat, 14 JUNI 2015, $<$ http://www.kpai.go.id/berita/kpai-pelaku-kekerasan-terhadap-anak-tiap-tahun-meningkat $>$ [accessed on $6 / 10 / 2018]$

Wibowo A, (2010). HakAsasiManusiadanImplementasinya di Indonesia, Unpad Press, Bandung,

Zainal Abidin (2013). PerlindunganHakAsasiManusia di Indonesia, MakalahdisampaikanpadaPelatihan HAM bagiPanitia RANHAM Prov. Sumatera Barat, Padang, 13 Juni 2013.

https://equitas.org/wp-content/uploads/2011/12/modul-2-hal-1-38.pdf [accessed on 10/10/2018]

http://shintaksari.multiply.com/journal/item/273/

http://www.pktpa.org/index.php/undang-undang-perlindungan-anak-belum-konsekuen dilaksanakan(Thursday, 16 April 2009 16:07)

Pasal 2 Undang-undangNomor 4 Tahun 1979 tentangKesejahteraanAnak 